\title{
Экономика постсоветского пространства: \\ ожидавшееся и неожиданное
}

Ю.С. ЕРШОВ, Институт экономики и организации промышленного производства СО РАН, Новосибирск. E-mail: eryus@mail.ru

В статье анализируются итоги развития экономик бывших союзных республик, на которые наиболее существенное влияние должно было оказать изменение внешних условий их развития в связи с переходом ранее внутренней торговли в межгосударственную по ценам мирового рынка и необходимостью каждого из государств постсоветского пространства самостоятельно находить источники финансирования дефицита своего торгового и в целом платежного баланса. Главная составляющая анализа - особенности экономического взаимодействия этих государств с Россией, которая, несмотря на заметное ослабление ее роли в качестве поставщика и потребителя товаров и услуг, продолжает оставаться для большинства из них важным экономическим партнером.

Ключевые слова: межотраслевые балансы, цены мирового рынка, сальдо внешней торговли, пространственная структура экономики, международные сопоставления, демография постсоветского пространства, международная миграция, этнический состав населения, трансграничные переводы

\section{Кому и зачем это было нужно?}

В самом начале 1990-х годов Госкомстат СССР впервые за всю историю разработки межотраслевых балансов союзных республик осуществил пересчет экспорта, импорта и межреспубликанских товарных потоков в мировые цены. Тем самым был получен ответ на вопрос о том, какими были бы значения сальдо торговых балансов республик, если бы торговля между ними осуществлялась по сложившимся на тот момент ценам мирового рынка. С какой целью выполнялись эти расчеты, официально не объявлялось. Логично предположить две версии. Первая - с чисто научной, познавательной. И вторая, более правдоподобная - показать почти всем республикам, что выход из СССР тяжело отразится на их экономиках и приведет к снижению уровня жизни.

Пересчет в мировые цены показателей ввоза, вывоза, экспорта и импорта для 1987 г. выявил, что РСФСР имеет огромное 
положительное сальдо - более 40 млрд так называемых «инвалютных рублей» ${ }^{1}$, или около 67 млрд долл., что примерно равно по покупательной способности, исходя из официальных данных об инфляции в США за 1988-2015 гг., 137 млрд современных долларов. Правда, в 1988 г. и 1989 г. вследствие изменений внешнеэкономической конъюнктуры положительное сальдо России сократилось соответственно до 31 и 32 млрд руб.

Естественный вывод - Россия де-факто является «кормилицей» остальной части СССР, и если бы межреспубликанская торговля осуществлялась по «правильным» ценам мирового рынка и на условиях эквивалентности товарообмена, то она могла бы получить большой дополнительный доход, а союзные республики вынуждены были бы в той или иной степени сократить масштабы потребления и инвестиций в свои экономики.

Конечно, такая интерпретация последствий изменения условий межреспубликанской торговли могла иметь место лишь у самых недалеких людей. Новые цены в сочетании с принципом эквивалентности товарообмена были просто несовместимы с прежними материально-вещественными связями, и часть рынка ближнего зарубежья² России пришлось бы потерять вследствие сокращения их емкости. Поставки нефти и газа с течением времени можно было бы перераспределить в пользу «дальнего зарубежья», а проблема реализации другой продукции вряд ли была бы успешно разрешена.

\section{И времена меняются,}

\section{и не товаром единым живут страны}

Следует отметить, что оценку особенностей межреспубликанских отношений и масштабов той «безвозмездной помощи», которую получали другие союзные республики от России благодаря выгодным для них отличиям внутренних цен от мировых, нельзя назвать полной и корректной. Не было даже приблизительных ретроспективных оценок показателей сальдо производства и потребления, в частности, до энергетического кризиса 1970-х, когда мировая цена на нефть была всего около 4 долл. за баррель. И каким было это сальдо для России, когда у нас еще не было

11 инвалютный рубль в 1987-1988 гг. примерно равен 1/0,6 = 1,67 долл. США. ложенны на территории бывших союзных РСФСР республик. ни «второго», ни «третьего Баку», а на Азербайджан приходилось две трети всей добываемой в СССР нефти.

Но кроме товаров, есть еще и услуги, и из того, что статистика не регистрировала межреспубликанский обмен услугами, не следует, что не было их ввоза и вывоза. В частности, итоги работы грузового транспорта союзных республик, включавшиеся, естественно, в их произведенный национальный доход, не регистрировались как экспорт услуг в Россию. А это должны были быть достаточно большие числа - экспортировались российские нефть и газ, и не только, и в основном через западные границы СССР, следовательно, их транзит через территорию Украины, Белоруссии, прибалтийских республик - по сути экспорт транспортных услуг этими республиками. И как изменились бы результаты при учете явно положительного сальдо торговли услугами тех республик, где традиционно отдыхали и лечились миллионы россиян - у Украины (в то время с Крымом), Грузии, Латвии. А еще был и вывоз услуг рабочей силы из некоторых «трудоизбыточных» республик, прежде всего закавказских, в Россию. Трудовых мигрантов тогда образно называли «грачами», и сколько в целом они зарабатывали в России, и какие суммы увозили или переводили на свои малые родины - такой статистики не было.

Примерная оценка всех источников денежных поступлений в каждую из республик могла поменять картину межреспубликанских отношений в части оценки степени «донорства» и «реципиентства» республик, но статус России радикально не изменился бы - ни 137, ни 100 млрд в пересчете на современные доллары не могли быть компенсированы возможным положительным сальдо вывоза и ввоза услуг у отдельных республик и заработками «грачей».

Помимо банальной констатации значений торговых сальдо республик, предпринимались попытки более глубокого изучения особенностей межреспубликанских экономических отношений. Еще задолго до известных расчетов Госкомстата работавший под руководством академика А.Г. Гранберга коллектив сотрудников Института экономики и организации промышленного производства СО РАН провел исследование экономики страны на базе модели двухзонального (РСФСР - остальная часть страны) межотраслевого баланса, позволившего дополнить статистику 
прямых торговых связей показателями так называемого полного ввоза и вывоза не только продукции, но и затрат трудовых ресурсов и капитала [1]. Прямого отношения к проблеме - кто выигрывает или проигрывает в результате отличий советских цен от цен мирового рынка - эти исследования не имели, но тем не менее одним из их результатов был вывод о большей значимости взаимодействия с Россией совокупности всех остальных союзных республик, чем это следовало из анализа только прямых межреспубликанских торговых связей.

В начале 1990-х гг. был разработан инструмент коалиционного анализа, позволивший дать оценки последствий разрыва тех или иных межреспубликанских связей или, напротив, объединения той или иной совокупности республик в коалицию - своего рода единое экономическое пространство без каких-либо ограничений во взаимной торговле и, более того, без обязательств каждого из участников коалиции самостоятельно обеспечивать свои торговые балансы [2, 3].

Позднее были выполнены оценки значимости пересчета внутренних цен в мировые для получаемых значений сальдо торговых балансов бывших союзных республик, а также влияния отклонений фактических внутренних цен конечного потребления от «нормальных», определяемых внутренними затратами на производство, т. е. «освобожденных» от акцизов и дотаций. Эти расчеты показали, что измерения в мировых ценах действительно заметно увеличивают для большинства союзных республик отрицательные значения торговых сальдо. Равно как и внутренние цены конечного потребления - в ценах, «освобожденных» от акцизов и дотаций, абсолютные значения отрицательных торговых сальдо уменьшались, более того, у некоторых республик значения этих сальдо становились положительными [4].

Но результаты таких расчетов могли лишь объяснить причины большой несбалансированности межреспубликанского товарообмена, и к вопросу о том, что может быть после перехода к торговле по ценам мирового рынка, они прямого отношения не имели.

\section{Первая неожиданность - уже на старте}

Логично было ожидать, что вследствие относительного единообразия социальных норм потребления и условий оплаты труда максимальные объемы отрицательного сальдо производства и потребления при оценке в «правильных» ценах окажутся у республик с самыми низкими показателями произведенного национального дохода на душу населения. Таковыми в 1990 г. были Таджикистан, Узбекистан и Киргизия - с показателями соответственно 37,48 и 56\% от среднего значения по СССР.

Но результат оказался далеким от ожидаемого по такой логике. Так, для Эстонии с населением всего 1,57 млн чел. и с самым высоким показателем произведенного национального дохода на душу (126\% от среднего по СССР) отрицательное сальдо ввоза-вывоза (включая импорт и экспорт) в 1988 г. составило при оценке его в мировых ценах 1,30 млрд инвалютных рублей, в то время как для Таджикистана с населением более 5 млн чел. это сальдо было лишь 1,12 млрд. Для Латвии с населением в 2,7 млн чел., также превосходящей Россию по производству национального дохода на душу, отрицательное сальдо ввоза-вывоза составило 1,31 млрд, в то время как для Киргизии с населением 4,3 млн чел. - лишь 1,06 млрд руб. Узбекистан с населением около 20 млн чел. и очень низким показателем душевого национального дохода имел отрицательное сальдо ввоза-вывоза 2,54 млрд, а Литва с населением 3,6 млн чел. - 3,69 млрд руб., и у этой республики величина отрицательного сальдо в расчете на душу населения достигала максимума среди всех союзных республик - около 1000 руб. Если же делить не на душу населения, а на численность занятых в экономике, то получим примерно 2000 руб. А средняя заработная плата в Литве в 1998 г. составляла около 220 руб. в месяц. Иначе говоря, получалось, что три четверти фонда заработной платы Литва получала в качестве помощи от России, в том числе и через механизм более выгодных для республики по сравнению с мировыми советских цен.

У нас нет никаких прямых оснований считать, что Госкомстат СССР преднамеренно завысил масштабы «реципиентства» прибалтийских республик, поскольку они фактически стали инициаторами выхода из СССР и последующего его распада, чтобы именно им в первую очередь показать экономическую нецелесообразность этого выхода. Будем поэтому считать результаты пересчета немного странными, легко и просто не объяснимыми. И если их принять за истину, то можно было предположить, что после распада СССР и перехода бывших союзных республик 
во взаимной торговле на цены мирового рынка среди наиболее пострадавших от необходимости самостоятельно обеспечивать свой платежный баланс должны оказаться республики Прибалтики и Молдавия (республики с наибольшими значениями отрицательного сальдо в расчете на душу населения)

Следующую группу по масштабам потерянных доходов от неэквивалентной ранее торговли с Россией составили бы Казахстан, Армения и Грузия. Меньше всего должны были потерять от перехода на эквивалентный обмен в мировых ценах Азербайджан и Украина - у последней отрицательное сальдо внешних торговых связей в расчете на душу населения в 1988 г. составляло менее 60 инвалютных рублей.

Среди потенциально выигрывающих от перехода на мировые цены были только Туркмения (но размер выигрыша для нее был символическим) и Россия - последняя от изменения условий внешней торговли должна была получить более 200 руб. в расчете на душу населения.

Насколько сбылись ожидания в масштабах проигрыша и выигрыша от перехода на торговлю по мировым ценам и на принципах эквивалентности обмена, можно судить по данным таблицы 1 путем сравнения 1990 г. и 1995 г. (данные по ВВП для всех постсоветских стран имеются лишь с 1995 г.).

Россия, безусловно, «выиграла» в смысле увеличения своей доли в суммарном объеме производства всех стран постсоветского пространства - с 60,6\% к 1995 г. она возросла до 73,2\%. Возможно, последний показатель немного завышен, так как в некоторых странах часть итогов экономической деятельности могла просто не учитываться (Приднестровье, Абхазия, Нагорный Карабах).

Сильнее всего «провалились» экономики Молдавии, Грузии, Армении, Киргизии и Таджикистана, но в какой степени это было обусловлено переходом на новые цены и необходимостью самостоятельного обеспечения своих торговых балансов, а в какой - иными факторами, определить невозможно. Неожиданностью можно считать увеличение доли Казахстана - с 4,3 до 5,3\%. Но самым большим сюрпризом стало новое положение бывших прибалтийских республик и Украины - совокупные относительные потери первых от изменения условий внешнеэкономических связей оказались минимальными, а главный бывший «нахлебник» России - Литва - даже смогла увеличить свою долю в суммарном объеме производства. Доля же Украины снизилась в полтора раза, хотя переход на новые цены в торговле сулил ей относительно небольшие в расчете на душу населения потери.

Таблица 1. Динамика ВВП стран постсоветского пространства за 1995-2014 гг. (исходя из курсов валют, соответствующих паритету их покупательной способности - ППС)*

\begin{tabular}{|l|c|c|c|c|c|c|c|c|c|c|c|c|c|}
\hline \multirow{2}{*}{ Страна } & \multicolumn{9}{|c|}{ Млрд долл. США } \\
\cline { 2 - 17 } & $\mathbf{1 9 9 5}$ & $\mathbf{2 0 0 0}$ & $\mathbf{2 0 0 5}$ & $\mathbf{2 0 1 0}$ & $\mathbf{2 0 1 3}$ & $\mathbf{2 0 1 4}$ & $\mathbf{1 9 9 0}$ & $\mathbf{1 9 9 5}$ & $\mathbf{2 0 0 0}$ & $\mathbf{2 0 0 5}$ & $\mathbf{2 0 1 0}$ & $\mathbf{2 0 1 3}$ & $\mathbf{2 0 1 4}$ \\
\hline Россия & 1300,6 & 1530,6 & 2314,0 & 3031,0 & 3498,0 & 3576,8 & 60,64 & 73,22 & 73,00 & 70,72 & 69,39 & 68,42 & 68,19 \\
\hline Эстония & 11,6 & 16,9 & 26,8 & 29,0 & 35,2 & 36,8 & 0,69 & 0,65 & 0,81 & 0,82 & 0,66 & 0,69 & 0,70 \\
\hline Латвия & 15,1 & 21,0 & 35,2 & 38,4 & 46,5 & 48,4 & 1,14 & 0,85 & 1,00 & 1,08 & 0,88 & 0,91 & 0,92 \\
\hline Литва & 24,4 & 33,3 & 54,5 & 63,6 & 76,4 & 79,9 & 1,29 & 1,37 & 1,59 & 1,67 & 1,46 & 1,49 & 1,52 \\
\hline Белоруссия & 39,3 & 57,9 & 93,3 & 146,0 & 167,3 & 172,8 & 4,32 & 2,21 & 2,76 & 2,85 & 3,34 & 3,27 & 3,29 \\
\hline Украина & 196,4 & 193,5 & 315,6 & 351,7 & 392,6 & 371,8 & 16,59 & 11,06 & 9,23 & 9,65 & 8,05 & 7,68 & 7,09 \\
\hline Молдавия & 7,0 & 6,7 & 10,6 & 13,6 & 16,7 & 17,8 & 1,24 & 0,39 & 0,32 & 0,32 & 0,31 & 0,33 & 0,34 \\
\hline Грузия & 7,9 & 11,4 & 18,2 & 25,9 & 32,3 & 34,3 & 1,51 & 0,44 & 0,54 & 0,56 & 0,59 & 0,63 & 0,65 \\
\hline Армения & 5,1 & 7,0 & 14,2 & 18,9 & 23,2 & 24,4 & 0,97 & 0,29 & 0,33 & 0,43 & 0,43 & 0,45 & 0,47 \\
\hline Азербайджан & 19,5 & 29,7 & 59,1 & 138,9 & 158,8 & 165,9 & 1,64 & 1,10 & 1,42 & 1,81 & 3,18 & 3,11 & 3,16 \\
\hline Казахстан & 93,2 & 114,5 & 210,7 & 313,5 & 396,2 & 420,0 & 4,33 & 5,25 & 5,46 & 6,44 & 7,18 & 7,75 & 8,01 \\
\hline Узбекистан & 37,0 & 48,6 & 70,8 & 117,3 & 156,8 & 172,3 & 3,38 & 2,08 & 2,32 & 2,16 & 2,69 & 3,07 & 3,28 \\
\hline Туркмения & 8,7 & 11,6 & 27,5 & 49,5 & 73,5 & 82,4 & 0,75 & 0,49 & 0,55 & 0,84 & 1,13 & 1,44 & 1,57 \\
\hline Киргизия & 5,7 & 8,1 & 11,0 & 14,9 & 18,3 & 19,2 & 0,85 & 0,32 & 0,39 & 0,34 & 0,34 & 0,36 & 0,37 \\
\hline Таджикистан & 4,7 & 5,9 & 10,4 & 15,8 & 20,7 & 22,4 & 0,67 & 0,26 & 0,28 & 0,32 & 0,36 & 0,40 & 0,43 \\
\hline Итого & 1776,2 & 2096,7 & 3271,9 & 4368,0 & 5112,5 & 5245,2 & 100 & 100 & 100 & 100 & 100 & 100 & 100 \\
\hline
\end{tabular}

* 1990 г. - долясоюзныхреспубликвпроизведенномнациональномдоходе СССР. Данные по ВВП России для сопоставимости с другими странами приведены такими, какими они были до пересчета итогов последних лет в соответствии с СНC 2008. Данные по ВВП Молдавии и Грузии не включают экономических итогов Приднестровья, Абхазии и Южной Осетии

Не менее интересным и неожиданным стало падение доли России в суммарном ВВП постсоветского пространства после 2000 г. - в период быстрого и значительного улучшения для нее внешнеэкономической конъюнктуры в части роста цен на нефть, газ, уголь, металлы. Основную роль в этом сыграли «новые азиатские нефтегазовые тигры» - Казахстан и Азербайджан. Эти страны почти вдвое увеличили свои доли в суммарном производстве постсоветского пространства по сравнению с 1990 г. Главная причина - многократный рост объемов добычи нефти: в Казахстане ее добыча к 2013 г. превысила 81 млн т (в 1990 г. здесь добывалось всего 25,8 млн т), в разы выросла и добыча 
газа - до 42,3 млрд м³ (в 1990 г. - 7,1 млрд м³). То же и в Азербайджане - с 12,5 млн т в 1990 г. до 50,8 млн т в 2010 г. возросла добыча нефти, с 9,9 до 16,7 млрд м $^{3}$ - добыча газа. В обеих странах в расчете на душу населения объем добычи нефти превысил аналогичный показатель по России.

\section{Странности международной статистики,}

\section{но «за неимением гербовой пишем на простой»}

Не все легко понять и объяснить. Например, удвоение доли Туркмении притом, что современные объемы добычи газа здесь меньше, чем в советский период (в 2012 г. - 75 млрд м ${ }^{3}$ против 90 млрд в 1990 г.). Выросла добыча нефти - около 10 млн т против 7 млн т в 1990 г., но это не может объяснить очень высоких темпов роста ВВП в среднем за весь постсоветский период. Одна из вероятных гипотез - недостоверность туркменской статистики, которая является одной из самых закрытых. Нет оснований безоговорочно доверять и статистике всех других стран. Так, например, статистика Азербайджана регистрирует прирост физического объема ВВП в 2009 г. на 9,3\% [5], растет и номинальный ВВП (со 119 млрд долл. в 2008 г. до 131 млрд долл., исчисленных исходя из ППС), при очень сильном падении - более чем в 1,5 раза - среднегодовой цены нефти и примерно на треть - газа на мировом рынке (для намного «менее нефтегазовой» экономики России такое снижение вызвало спад на 7,8\%). Напротив, в 2011 г. при увеличении цены на нефть более чем на треть номинальный ВВП страны растет символически - до 142 млрд долл. против 139 в 2010 г. (только снижением добычи с 51 до 46 млн т это объяснить невозможно).

Далеко не все гладко и в части отображения международной статистикой российской экономики. Вспомним одну из главных задач, которую ставил когда-то Президент РФ - в течение 10 лет удвоить ВВП страны. По данным Росстата, эта задача не была выполнена ни к 2010 г. по сравнению с 2000 г., ни к 2013 г. по сравнению с 2003 г., когда она была озвучена. Произведение индексов физического объема ВВП дает за 2001-2010 гг. величину 1,60, еще меньше результат за 2004-2013 гг. - 1,48.

А теперь обратимся к статистике международных сопоставлений, публикуемой в последнем разделе Российского статистического ежегодника [6] (эти же данные есть и на сайте Росстата).
2002 г. - душевой ВВП России составляет лишь 22\% от американского уровня, данные за 2008 г. - уже 43\%. Если учесть, что в США в 2008 г. физический объем ВВП составил почти $115 \%$ от уровня 2002 г., то можно констатировать, что ВВП России был более чем удвоен всего за шесть лет (небольшие поправки на динамику численности населения - рост примерно на 6\% в США и снижение в РФ на 2,2\% не изменяют результат). Конечно, если предположить, что $22 \%$ - это на самом деле $22,49 \%$, а $43 \%$ - это $42,50 \%$, то до удвоения немного не дотягиваем, получим лишь 1,89. Но при добавлении индексов физического объема ВВП России за 2001 г. и 2002 г. (105,1 и 104,7\%) уже будет более чем удвоение, правда, не за шесть, а за восемь лет.

Очевидно, что у Росстата, как и у президента и правительства, нет оснований занижать индексы физического объема ВВП России, приходится просто констатировать факт недостоверности пары $22 \%$ - 43\%. Вполне вероятно, что нельзя полностью доверять и статистике каких-то других стран. Но другой нет.

Самым неприятным для России итогом стал тот факт, что вопреки ожиданиям экономика Эстонии имеет более высокие душевые показатели ВВП (табл. 2), у Литвы практически такой же показатель, как и у России. И Латвия не очень сильно отстает от нас. А ведь в этих республиках нет ни нефти, ни газа, ни угля, ни многого другого. Чем же объяснить «прибалтийский феномен» - бывшие в передовиках в условиях, когда расчеты осуществлялись в советских ценах, ими же и остались при товарообмене с другими странами по мировым ценам?

Одна из возможных причин - возрастная структура населения этих стран и, соответственно, пониженная демографическая нагрузка на работающую его часть. Но эта причина была бы весомой при сравнении с государствами Центральной Азии, где высокая рождаемость - одна из важнейших причин низких душевых показателей ВВП (если бы, например, все женщины Таджикистана решили в каком-то году не рожать детей, то по итогам этого года душевой ВВП республики стал бы на 2,5 п. п. выше, чем при современном количестве ежегодно рождающихся). И если в государствах Балтии занятым в экономике считается примерно каждый второй, то в Таджикистане или Узбекистане лишь каждый четвертый житель. Значительная часть «незанятых», особенно женщин, в этих странах работают и, возможно, 
даже больше, чем «занятые» эстонки или латышки, но итоги труда статистика не включает в ВВП, поскольку их продукция не является товарной. Не включала их в национальный доход и советская статистика. По этой причине различия в формальных показателях душевых ВВП нельзя интерпретировать как различия в результатах производственной деятельности в широком смысле слова, включающей не только товарную его часть, но и результаты самообслуживания.

Таблица 2. Душевые ВВП по ППС в 2013 г. (оценка МВФ)

\begin{tabular}{|l|c|c|l|c|c|}
\hline \multicolumn{1}{|c|}{ Страна } & Долл./чел. & \% от США & \multicolumn{1}{c|}{ Страна } & Долл./чел. & \% от США \\
\hline США & 52615 & & Грузия & 8527 & 16,2 \\
\hline Россия & 25897 & $49,2^{*}$ & Армения & 7762 & 14,8 \\
\hline Эстония & 26638 & 50,6 & Азербайджан & 17135 & 32,6 \\
\hline Латвия & 22464 & 42,7 & Казахстан & 23081 & 43,9 \\
\hline Литва & 25911 & 49,2 & Узбекистан & 5185 & 9,9 \\
\hline Белоруссия & 17678 & 33,6 & Туркмения & 14022 & 26,7 \\
\hline Украина & 9151 & 17,4 & Киргизия & 3161 & 6,0 \\
\hline Молдавия & 4698 & 8,9 & Таджикистан & 2540 & 4,8 \\
\hline
\end{tabular}

* 49,2\% - это не результат высоких темпов экономического роста России после 2011 г., когда считалось, что наш показатель составляет 45\% от американского, а результат перехода на СНС 2008 - мы стали «правильно считать», т. е. как они Так же уже считают и в государствах Балтии, у другихстран показатели душевого ВВП могут быть немного занижены, так как не все из них перешли на СНС 2008 .

При сравнении государств Балтии и России демографический фактор не может внести существенный вклад в объяснение факта близости душевых показателей ВВП. Хотя первые по показателям рождаемости находятся в конце списка стран мира (9-10 родившихся в год в расчете на 1000 чел. населения), Россия их опережает ненамного, а наличие трудовых мигрантов и пониженный пенсионный возраст приводят к тому, что отношение занятых в экономике к общей численности населения у них и у нас примерно одинаковое.

Главная причина относительного успеха бывших прибалтийских республик - по-видимому, их специализация в международном разделении труда, сформировавшаяся во многом благодаря России. Такой вывод был сделан при анализе причин очень высокой межрегиональной дифференциации душевых показателей ВРП российских субъектов Федерации - одним из факторов повышенных показателей является высокий удельный вес в структуре производства видов деятельности с большими значениями добавленной стоимости на одного занятого (финансы, оптовая торговля, транспорт, отдельные виды услуг) [7]. Государства Балтии не являются, конечно, международными финансовыми центрами, но торговое посредничество и транзит грузов через их территорию - это также достаточно доходные виды деятельности. Формальный экспорт из России в Прибалтику намного превышает ее потребности в российских товарах, следовательно, фактически имеет место посредничество в транзите грузов из России.

Помимо специализации, существенное значение должны иметь и такие факторы, как помощь западных стран своим главным союзникам на постсоветском пространстве, как «бескорыстная», так и корыстная - внешний долг Литвы к концу 2013 г. достиг 63\% от ВВП, Эстонии - 110\%, Латвии - 131\%. Пока объем новых заимствований превышает выплаты по старым, этот приток капитала в страну содействует росту ВВП и даже позволяет потреблять больше, чем производить (внешнеторговые балансы всех этих стран хронически отрицательные, и далеко не символически: у Латвии отрицательное сальдо торгового баланса в 2011-2013 гг. составляло около 3,5 млрд долл. в год, в период максимальных заимствований, перед 2009 г., достигало 6,5-7,2 млрд долл.). Более 7 млрд долл. ежегодно в 2007-2008 гг. достигал дефицит торгового баланса и у Литвы, у маленькой Эстонии в это же время дефицит превышал 4 млрд долл. в среднем за год. Он финансировался за счет больших объемов заимствований из-за рубежа. Конечно, эта «палка» имела и другой «конец», который во время финансового кризиса ударил по странам Балтии сильнее, чем по российской и другим нефтегазовым экономикам постсоветского пространства - падение физического объема ВВП в 2009 г. здесь было максимальным (несмотря на благоприятное для этих стран изменение внешнеэкономической конъюнктуры в части падения цен на энергоносители): Латвия $82,0 \%$, Эстония $-85,7 \%$, Литва $-85,3 \%$.

Как влияют на экономику стран Балтии те денежные средства, которые перечисляют и привозят на родину трудовые мигранты из этих стран, доступная статистика ответа не дает, но наверняка объемы этих поступлений в расчете на одного мигранта, работающего в Европе, в разы превышают те суммы, которые перечисляет из России гражданин Узбекистана или Киргизии.

Изменения пространственной структуры производства на территории бывшего СССР и усиление межстрановых различий 2 ЭКО. - 2016. - №10 
в душевых показателях производства и потребления не вызвали адекватных изменений в размещении главной составляющей производительных сил - потенциальных трудовых ресурсов, численность которых прямо зависит от численности населения.

Тройка лидеров по темпам роста населения осталась прежней - Таджикистан, Узбекистан и Туркмения. В тройке аутсайдеров произошла полная замена состава - место Украины, России и Белоруссии заняли Латвия, Эстония и Грузия. Наиболее радикальное изменение демографического тренда произошло в Армении, которая оказалась единственной страной с сокращающимся населением, несмотря на положительные значения естественного прироста. У всех остальных стран с уменьшившейся численностью населения показатели естественного прироста в целом за период после 1990 г. были отрицательными, у стран с возросшей численностью населения - положительными (табл. 3).

\section{Таблица 3. Динамика населения стран} постсоветского пространства в 1990-2014 гг. *

\begin{tabular}{|c|c|c|c|c|c|c|c|c|c|c|}
\hline \multirow[b]{2}{*}{ Страна } & \multicolumn{4}{|c|}{ Тыс. чел. } & \multicolumn{4}{|c|}{ \% к итогу } & \multirow[b]{2}{*}{$\begin{array}{c}2014 \\
1990\end{array}$} & \multirow[b]{2}{*}{$\begin{array}{l}1990 / \\
1966\end{array}$} \\
\hline & 1990 & 2000 & 2010 & 2014 & 1990 & 2000 & 2010 & 2014 & & \\
\hline Россия & 147665 & 146890 & 142856 & 143667 & 51,27 & 50,82 & 49,66 & 49,24 & 97,3 & 116,1 \\
\hline Эстония & 1571 & 1372 & 1340 & 1276 & 0,55 & 0,47 & 0,47 & 0,44 & 81,2 & 121,1 \\
\hline Латвия & 2668 & 2382 & 2248 & 2002 & 0,93 & 0,82 & 0,78 & 0,69 & 75,0 & 117,2 \\
\hline Литва & 3694 & 3512 & 3329 & 2943 & 1,28 & 1,22 & 1,16 & 1,01 & 92,9 & 123,6 \\
\hline Белоруссия & 10190 & 9988 & 9491 & 9469 & 3,54 & 3,46 & 3,30 & 3,25 & 92,9 & 117,0 \\
\hline Украина & 51557 & 49115 & 45783 & 45246 & 17,90 & 16,99 & 15,92 & 15,51 & 87,8 & 113,2 \\
\hline Молдавия & 4362 & 4293 & 4113 & 4063 & 1,51 & 1,49 & 1,43 & 1,39 & 93,2 & 129,6 \\
\hline Грузия & 5424 & 4715 & 4436 & 4491 & 1,88 & 1,53 & 1,54 & 1,54 & 82,8 & 120,4 \\
\hline Армения & 3515 & 3227 & 3055 & 3017 & 1,22 & 1,12 & 1,06 & 1,03 & 85,8 & 157,0 \\
\hline Азербайджан & 7132 & 8033 & 8998 & 9477 & 2,48 & 2,79 & 3,13 & 3,24 & 132,9 & 153,7 \\
\hline Казахстан & 16690 & 14900 & 16205 & 17165 & 5,79 & 5,17 & 5,63 & 5,87 & 102,8 & 138,5 \\
\hline Узбекистан & 20322 & 24488 & 28001 & 30493 & 7,06 & 8,49 & 9,73 & 10,43 & 150,0 & 195,4 \\
\hline Туркмения & 3622 & 4800 & 4913 & 5193 & 1,26 & 1,66 & 1,71 & 1,78 & 143,4 & 188,9 \\
\hline Киргизия & 4367 & 4900 & 5418 & 5777 & 1,52 & 1,70 & 1,88 & 1,98 & 132,3 & 167,0 \\
\hline Таджикистан & 5248 & 6100 & 7530 & 8161 & 1,82 & 2,11 & 2,62 & 2,79 & 155,5 & 205,3 \\
\hline Всего & 288027 & 288435 & 287716 & 292440 & 100 & 100 & 100 & 100 & 101,5 & 124 \\
\hline
\end{tabular}

* Данные по Молдавии - с оценкой населения Приднестровья (в официальные данные молдавской статистики оно не включается), данные по Азербайджану - с оценкой населения Нагорного Карабаха, данные по Грузии - с оценкой населения Абхазии и Южной Осетии. Данные по Украине (начало 2014 г.) еще включают население Крыма.

\section{Особенности межнационального развода}

Общая для всех бывших союзных с Россией республик закономерность - рост доли титульной нации в численности их населения. На темпы этого роста самое большое влияние оказали масштабы эмиграции нетитульного населения. Влияние межнациональных различий в темпах естественного прироста населения было, по всей видимости, на порядок меньшим. Так, в Эстонии доля эстонцев в 1989 г. (последняя советская перепись населения) составляла $61,5 \%$, оценка на 2010 г. $68,8 \%$, доля титульного населения в Латвии увеличилась с 52,1 до 62,1\% (2011 г.), в Литве - с 79,6 до 84,2\% (2011 г.), в Белоруссии - с 77,9 до 83,7\% (2008 г.), на Украине - с 72,7 до 77,8\% (2001 г.), в Грузии - с 70 до 84\% (2002 г.), население Армении стало почти моноэтничным уже в начале века (по переписи 2001 г. армяне составили 98,6\% населения страны), доля азербайджанцев в Азербайджане выросла с 82,7 до 91,6\% (2009 г., но это включая оценку населения Нагорного Карабаха, где живут почти одни армяне), в Казахстане - с 39,7 до 63,1\% (2009 г.), в Узбекистане - с 71,4 до 82\% (2013 г.), в Киргизии с 52 до $72 \%$ (2012 г.), в Туркмении - с 72,0 до 78,6\% (2010 г.), в Таджикистане - с 62 до 84\% (2010 г.).

Напротив, доля русских по сравнению с 1989 г. снизилась в Эстонии с 30,3 до 25,6\%, в Латвии - с 34 до 26,9\%, в Литве - с 9,4 до 5,8\%, в Белоруссии - с 13,2 до 8,3\%, на Украине - с 22,1 до 17,3\%, в Грузии - с 6,3 до $1,6 \%$, в Азербайджане - с 5,6 до $1,3 \%$, в Армении - с 1,6 до 0,4\%, в Казахстане - с 37,8 о $23,7 \%$, в Узбекистане - с 8,4 до 2,6\%, в Киргизии - с 21,5 до 6,9\%, в Туркмении - с 9,5 до 3,2\%, в Таджикистане - с 7,6 до $0,5 \%$. Аналогичным было изменение долей представителей других «русскоязычных» народов - евреев, немцев, татар, башкир и т. д., а также украинцев и белорусов, ранее проживавших за пределами Белоруссии и Украины.

Характерно то, что на масштабы эмиграции «русскоязычного» населения степень официальной русофобии или антироссийской политики властей не повлияла решающим образом - как раз напротив, самые крупные русские общины сохранились в Эстонии и Латвии. А в формально дружественных с Россией среднеазиатских странах их численность сократилась в разы. 
В отдельных государствах при сокращении доли имел место абсолютный рост численности нетитульных народов - так, в Казахстане увеличивалось число узбеков, таджиков, киргизов, в Узбекистане значительно выросла таджикская община, достигшая сейчас около 1,5 млн чел. (по переписи 1989 г. таджиков здесь было лишь 934 тыс.).

Единственное исключение из общего правила - Россия, здесь доля основной титульной нации - русской - снизилась с 81,5 до 77,7\% (2010 г.). Зато существенно возросла численность ряда национальных общин - выходцев в том или ином колене из бывших союзных республик: количество армян - с 532 тыс. (1989 г.) до 1184 тыс. (2010 г.), азербайджанцев - с 336 до 603 тыс., узбеков - со 127 до 290 тыс., таджиков - с 38 до 200 тыс., киргизов - с 42 до 103 тыс. И это только те, которые входят в состав постоянного населения России. При этом их численность результаты последней переписи, по-видимому, занижают - в 2010 г. 5,6 млн чел. не указали свою национальность (в 1989 г. таковых было лишь 15 тыс.) - логично предположить, что среди не указавших национальность людей доля прибывших из ближнего зарубежья больше, чем среди указавших. Так что «новая историческая общность», как назвал когда-то Л.И. Брежнев советский народ, продолжает формироваться, но уже на более ограниченной территории.

Главная причина усиления полиэтнизма населения России - миграция из бывших союзных республик. Россия имеет положительный миграционный прирост населения за счет всех без исключения государств постсоветского пространства, в том числе и новых, почти никем еще не признанных (табл. 4). И если в 1990-х гг. основную часть этого прироста обеспечивало попавшее в очень некомфортные условия «русскоязычное» население, то в настоящее время в Россию переезжает в основном титульное население этих стран (исключением, возможно, является состав мигрирующих из государств Балтии и Казахстана, где русскоязычные общины еще велики). Явно выраженного тренда к увеличению или ослаблению миграционного потока из ближнего зарубежья нет, можно лишь констатировать уменьшение миграционного притока в неблагоприятные для экономики России годы (2010 г. - итог кризиса 2009 г., 2014 г. - существенное сокращение общего притока ослаблено ростом мигрантов с Украины, в 2015 г. миграционный прирост еще более сократился).

Таблица 4. Сальдо миграционного прироста населения России за счет стран постсоветского пространства в 2007-2014 гг., чел. *

\begin{tabular}{|l|c|c|c|c|c|c|c|c|}
\hline \multicolumn{1}{|c|}{ Страна } & $\mathbf{2 0 0 7}$ & $\mathbf{2 0 0 8}$ & $\mathbf{2 0 0 9}$ & $\mathbf{2 0 1 0}$ & $\mathbf{2 0 1 1}$ & $\mathbf{2 0 1 2}$ & $\mathbf{2 0 1 3}$ & $\mathbf{2 0 1 4}$ \\
\hline Эстония & 228 & 175 & 315 & 431 & 1322 & 924 & 749 & 303 \\
\hline Латвия & 616 & 490 & 497 & 672 & 1169 & 996 & 928 & 607 \\
\hline Литва & 261 & 240 & 270 & 280 & 617 & 502 & 553 & 161 \\
\hline Белоруссия & 728 & 1911 & 2944 & 1995 & 7560 & 10249 & 3717 & 6722 \\
\hline Украина & 40956 & 40123 & 40183 & 21230 & 37286 & 36995 & 36411 & 84939 \\
\hline Молдавия & 13461 & 14968 & 15785 & 11197 & 18807 & 18645 & 20628 & 17498 \\
\hline Грузия & 9992 & 8234 & 6825 & 4786 & 6909 & 6927 & 6112 & 4178 \\
\hline Армения & 30023 & 34184 & 34770 & 19182 & 31747 & 31998 & 32179 & 23953 \\
\hline Азербайджан & 19613 & 22073 & 21744 & 13389 & 21061 & 18102 & 17246 & 12350 \\
\hline Казахстан & 30047 & 32481 & 31598 & 20533 & 30298 & 36663 & 40156 & 40768 \\
\hline Узбекистан & 52080 & 42570 & 41862 & 23266 & 62286 & 56343 & 67266 & 36733 \\
\hline Туркмения & 4735 & 3872 & 3274 & 2178 & 4333 & 3887 & 3821 & 2598 \\
\hline Киргизия & 24063 & 23366 & 22591 & 20260 & 40586 & 24108 & 19812 & 15255 \\
\hline Таджикистан & 16845 & 20080 & 26418 & 17494 & 34017 & 31393 & 33649 & 19340 \\
\hline Абхазия & & & & 732 & 2254 & 1536 & 2009 & 868 \\
\hline Южная Осетия & & & & 23 & 611 & 504 & 275 & 49 \\
\hline Всего & 243648 & 244767 & 249076 & 157648 & 300863 & 279772 & 285511 & 266322 \\
\hline
\end{tabular}

* В таблице представлены прямые данные о миграции населения. Данные до 2011 г. не совпадают с расчетным сальдо миграции, определяемым исходя из данных о численности населения, числе родившихся и числе умерших. Расчетное сальдо миграции заметно превосходило прямые данные.

С большой вероятностью можно ожидать существенного увеличения миграционного прироста в случае выхода экономики России на устойчивую позитивную траекторию роста, в том числе и в связи с обозначившимися последствиями демографической ямы, обусловленной резким падением рождаемости в 1990-х: число вступающих в трудоспособный возраст россиян резко сократилось.

\section{От нуля - к вынужденному профициту}

Помимо пространственной структуры производства следует отметить одно очень важное изменение в экономике постсо- 
ветского пространства в целом. Если торговое сальдо СССР было близким к нулевому, то в настоящее время суммарное торговое сальдо всех государств превышает 200 млрд долл. Львиную долю его формирует Россия, но и остальная часть бывшего СССР в последние годы в совокупности также имеет профицит торгового баланса (в 1990-е гг. и в начале 2000-х эта часть постсоветского пространства еще отличалась отрицательными значениями торгового сальдо). И хотя у многих стран имеет место хронически отрицательное сальдо (самое большое у Украины - в 2011-2013 гг. свыше 14 млрд долл. в среднем за год), оно с лихвой компенсируется большими положительными значениями у Азербайджана и особенно у Казахстана (у последнего в 2011-2013 гг. в среднем более 40 млрд долл.).

Чем объяснить столь радикальное изменение характера внешней торговли? Ответ на этот вопрос применительно к России: наша страна просто вынуждена иметь большое положительное внешнеторговое сальдо, чтобы расплачиваться с иностранными инвесторами - владельцами собственности на ее территории, с кредиторами и иностранными рабочими [8]. Если судить по последним опубликованным данным о платежных балансах [5], эти же причины вынуждают иметь положительное торговое сальдо Азербайджан и Казахстан по статье «первичные доходы» платежного баланса за 2012 г. у Азербайджана показатель составляет 4,2 млрд долл. со знаком минус, с таким же знаком, но намного больше, он у Казахстана - 28 млрд долл. Кроме того, этим странам необходимо компенсировать достаточно большие отрицательные значения сальдо услуг (соответственно 2,6 и 7,8 млрд долл.). Отрицательные значения по статье «первичные доходы» имеют и все остальные страны, для которых опубликованы такие данные.

Отрицательные сальдо торгового баланса отчасти компенсируются положительным сальдо услуг только в государствах Балтии, Белоруссии и Украине. Еще один источник покрытия его дефицита - денежные переводы физических лиц из-за рубежа - как трудовых мигрантов, так и ставших уже резидентами других стран, помогающими своим родственникам. Статистика Банка России приводит объемы таких переводов из России: в отношениях с большинством государств у нас объем перечислений «туда» больше, чем «оттуда»- исключениями являются лишь Казахстан и Туркмения (табл. 5). Наиболее значима роль таких поступлений для экономик Узбекистана, Таджикистана, Армении и Молдавии.

Таблица 5. Сальдо трансграничных переводов физических лиц в 2007-2015 гг., млн долл.

\begin{tabular}{|l|c|c|c|c|c|c|c|c|c|}
\hline \multicolumn{1}{|c|}{ Страна } & $\mathbf{2 0 0 7}$ & $\mathbf{2 0 0 8}$ & $\mathbf{2 0 0 9}$ & $\mathbf{2 0 1 0}$ & $\mathbf{2 0 1 1}$ & $\mathbf{2 0 1 2}$ & $\mathbf{2 0 1 3}$ & $\mathbf{2 0 1 4}$ & $\mathbf{2 0 1 5}$ \\
\hline Эстония & 101 & -2 & 18 & -5 & 14 & 46 & -19 & -86 & -144 \\
\hline Латвия & 137 & -44 & 34 & -38 & -230 & -195 & -544 & -727 & -428 \\
\hline Литва & 24 & -34 & -39 & -51 & -88 & -106 & -94 & -123 & -29 \\
\hline Белоруссия & -45 & -76 & -61 & -140 & -192 & -216 & -267 & -207 & -108 \\
\hline Украина & -1659 & -1924 & -1374 & -1913 & -2415 & -2737 & -2827 & -1877 & -970 \\
\hline Молдавия & -767 & -1092 & -715 & -810 & -1028 & -1118 & -1180 & -1081 & -481 \\
\hline Грузия & -609 & -738 & -362 & -580 & -704 & -772 & -820 & -719 & -365 \\
\hline Армения & -940 & -1279 & -765 & -960 & -1176 & -1332 & -1331 & -1230 & -660 \\
\hline Азербайджан & -755 & -990 & -656 & -792 & -929 & -1003 & -1093 & -879 & -569 \\
\hline Казахстан & 640 & 315 & 415 & 377 & 463 & 646 & 680 & 809 & 1082 \\
\hline Узбекистан & -1444 & -2659 & -1807 & -2606 & -3933 & -5253 & -6100 & -4978 & -2548 \\
\hline Туркмения & -23 & -37 & -15 & -11 & -6 & -3 & 8 & 44 & 96 \\
\hline Киргизия & -639 & -1084 & -798 & -963 & -1319 & -1577 & -1694 & -1637 & -1061 \\
\hline Таджикистан & -1578 & -2413 & -1638 & -2126 & -2856 & -3290 & -3587 & -3349 & -1966 \\
\hline Абхазия & & & -18 & -54 & -61 & -61 & -59 & -58 & -40 \\
\hline Южная Осетия & & & -6 & -10 & -11 & -1 & -7 & -5 & -4 \\
\hline Всего & -7557 & -12060 & -7787 & -10682 & -14471 & -16972 & -18934 & -16103 & -8245 \\
\hline
\end{tabular}

* Эти официальные цифры - перечисления по банковским каналам и почтовые переводы - характеризуют роль поступлений из России в неполном объеме. Какая-та часть денег перевозится в наличной форме.

\section{Дезинтеграция экономики постсоветского пространства - конца пока не видно}

Помимо перехода экономики постсоветского пространства в целом к необходимости производить больше, чем потреблять, за последние 20 с лишним лет имела место ее заметная дезинтеграция, выразившаяся в заметном снижении роли внутреннего рынка в экспортных и импортных поставках.

Еще в 1995 г. на страны постсоветского пространства приходилось 22,4\% всего российского экспорта, в 2013 г. - лишь $18,2 \%$. Абсолютный объем экспорта из России в ближнее зару- 
бежье вырос с 16,8 до 94,7 млрд долл., но остается в физическом выражении меньшим, чем в конце советского периода (табл. 6).

Таблица 6. Экспорт товаров из России

и импорт в Россию в 1995-2013 гг., млн долл.

\begin{tabular}{|l|c|c|c|c|c|c|c|c|}
\hline \multirow{2}{*}{\multicolumn{1}{|c|}{ Страна }} & \multicolumn{5}{|c|}{ Экспорт } & \multicolumn{4}{c|}{ Импорт } \\
\cline { 2 - 10 } & $\mathbf{1 9 9 5}$ & $\mathbf{2 0 0 2}$ & $\mathbf{2 0 1 0}$ & $\mathbf{2 0 1 3}$ & $\mathbf{1 9 9 5}$ & $\mathbf{2 0 0 2}$ & $\mathbf{2 0 1 0}$ & $\mathbf{2 0 1 3}$ \\
\hline Эстония & 411 & 1690 & 1714 & 3968 & 275 & 104 & 555 & 788 \\
\hline Латвия & 795 & 699 & 5895 & 10422 & 376 & 151 & 672 & 803 \\
\hline Литва & 1081 & 1695 & 3549 & 6001 & 387 & 311 & 956 & 1118 \\
\hline Белоруссия & 2965 & 5922 & 18081 & 20333 & 2185 & 3977 & 9954 & 14264 \\
\hline Украина & 7149 & 5885 & 23148 & 23813 & 6617 & 3230 & 14047 & 15794 \\
\hline Молдавия & 413 & 269 & 1108 & 1321 & 636 & 281 & 421 & 417 \\
\hline Грузия & 49 & 91 & 291 & 398 & 58 & 69 & 35 & 104 \\
\hline Армения & 127 & 95 & 700 & 864 & 75 & 57 & 159 & 352 \\
\hline Азербайджан & 86 & 277 & 1562 & 2942 & 107 & 87 & 386 & 636 \\
\hline Казахстан & 2555 & 2403 & 10690 & 17678 & 2675 & 1946 & 4449 & 5980 \\
\hline Узбекистан & 824 & 453 & 1889 & 2805 & 889 & 344 & 1557 & 1257 \\
\hline Туркмения & 93 & 143 & 757 & 1430 & 179 & 32 & 148 & 139 \\
\hline Киргизия & 105 & 104 & 991 & 2029 & 101 & 74 & 393 & 110 \\
\hline Таджикистан & 190 & 68 & 673 & 724 & 167 & 66 & 214 & 38 \\
\hline Итого & 16843 & 19794 & 71048 & 94728 & 14727 & 10729 & 33946 & 41800 \\
\hline Экспорт, всего & 82419 & 102068 & 392674 & 521835 & 62603 & 58418 & 245680 & 341269 \\
\hline Доля ближнего & 20,4 & 19,4 & 18,1 & 18,2 & 23,5 & 18,4 & 13,8 & 12,3 \\
\hline зарубежья, \% & 2,4 & & & & &
\end{tabular}

Намного более значительно снижение доли ближнего зарубежья в российском импорте: в 1995 г. она составляла 23,5\% (14,7 млрд долл.), к 2013 г. упала до 12,3\%, при росте абсолютного объема до 41,8 млрд долл. в текущих ценах.

Как и в последние годы советского периода, Россия всегда имела положительное сальдо товарообмена с совокупностью всех бывших союзных республик. Но в начале 1990-х оно стремительно сокращалось по абсолютной величине, составив к 1995 г. всего 2,1 млрд долл. (в 1989 г. положительное сальдо межреспубликанского обмена для России составляло более 28 млрд инвалютных рублей, или около 46 млрд долл.). С отдельными странами у России временами было даже отрицательное сальдо товарообмена. И лишь начиная с 2007 г. Россия стабильно имеет положительное сальдо внешней торговли со всеми бывшими союзными республиками.

Следует отметить, что по формальной статистике внешней торговли нельзя судить о реальной географии товародвижения и конечных потребителей. Экспорт регистрируется как экспорт, например, в Латвию, если товар из России приобрела фирма, зарегистрированная в Латвии. Фактически же товар может проследовать транзитом в третью страну или даже вообще не побывать на латвийской территории - маленькой Латвии для внутреннего потребления российские товары на сумму 10,4 млрд долл. (в 2014 г. - 12,8 млрд долл.) просто не нужны. В общем импорте этой страны доля поставок из России еще в 2010 г. составила 64\%, в 2013-2014 гг. превысила 80\% - очевидно, что большая часть этого импорта поступает в страну для перепродажи. По показателю отношения импорта из России к ВВП Латвия находится на первом месте и более чем вдвое превосходит даже Белоруссию. В лидерах по этому показателю находятся также и Эстония и Литва, в аутсайдерах - Грузия, Азербайджан, Узбекистан и Туркмения.

Россия в качестве рынка сбыта экспортной продукции особенно значима для Армении: в 2010 г. ее доля в общем экспорте страны превысила $82 \%$, что более чем вдвое превышает показатель Белоруссии - самого крупного поставщика товаров в Россию. Менее всего значим российский рынок для Грузии, Азербайджана и Туркмении - в их суммарном экспорте доля России не превышает и $2 \%$.

По динамике обмена услугами и товарами темпы дезинтеграции экономик постсоветского пространства еще более выразительны, чем в части экспорта и импорта товаров. Статистика в этой сфере имеется лишь начиная с 2002 г., а по всем странам ближнего зарубежья - лишь с 2005 г., но и за этот относительно короткий период экономические связи между Россией и остальной частью постсоветского пространства стали значительно слабее. Если в 2002 г. на долю ближнего зарубежья приходилось 24\% всего экспорта услуг Россией, то к 2013 г. его доля снизилась до 17,5\%. Еще более высокими темпами падала доля импорта из ближнего зарубежья - с 18 до 9,7\% за аналогичный период (в 2014 г. события на Украине привели к дальнейшему снижению этого показателя до 8\%). 
С большинством стран Россия имеет положительное сальдо услуг, исключения - Латвия, Белоруссия, Украина и Грузия страны, играющие значительную роль в транзите грузов из России и в Россию (табл. 7).

Таблица 7. Экспорт услуг из России и импорт в Россию в 19952013 гг., млн долл. *

\begin{tabular}{|l|c|c|c|c|c|c|c|c|}
\hline \multirow{2}{*}{ Страна } & \multicolumn{5}{|c|}{ Экспорт } & \multicolumn{4}{c|}{ Импорт } \\
\cline { 2 - 9 } & $\mathbf{2 0 0 5}$ & $\mathbf{2 0 1 0}$ & $\mathbf{2 0 1 2}$ & $\mathbf{2 0 1 3}$ & $\mathbf{1 9 9 5}$ & $\mathbf{2 0 0 2}$ & $\mathbf{2 0 1 0}$ & $\mathbf{2 0 1 3}$ \\
\hline Эстония & 160 & 275 & 472 & 454 & 133 & 316 & 286 & 305 \\
\hline Латвия & 230 & 496 & 400 & 411 & 159 & 262 & 488 & 532 \\
\hline Литва & 239 & 237 & 405 & 666 & 121 & 220 & 376 & 425 \\
\hline Белоруссия & 309 & 659 & 849 & 1473 & 683 & 1149 & 1693 & 2059 \\
\hline Украина & 1146 & 2132 & 2375 & 2392 & 2443 & 3492 & 4343 & 4486 \\
\hline Молдавия & 126 & 353 & 421 & 449 & 114 & 261 & 228 & 201 \\
\hline Грузия & 59 & 43 & 55 & 48 & 203 & 44 & 189 & 360 \\
\hline Армения & 142 & 296 & 344 & 360 & 107 & 262 & 288 & 329 \\
\hline Азербайджан & 204 & 510 & 540 & 527 & 170 & 252 & 276 & 272 \\
\hline Казахстан & 713 & 1689 & 1949 & 2223 & 723 & 773 & 1020 & 973 \\
\hline Узбекистан & 210 & 959 & 1262 & 1311 & 133 & 296 & 415 & 425 \\
\hline Туркмения & 63 & 183 & 589 & 374 & 31 & 92 & 45 & 47 \\
\hline Киргизия & 77 & 363 & 341 & 343 & 37 & 117 & 228 & 261 \\
\hline Таджикистан & 140 & 641 & 631 & 601 & 69 & 251 & 337 & 343 \\
\hline Итого & 5062 & 9415 & 11385 & 12296 & 6020 & 8910 & 11763 & 12500 \\
\hline Экспорт, всего & 28845 & 49159 & 62340 & 70123 & 40471 & 75279 & 108923 & 128382 \\
\hline Доля ближнего & 17,6 & 19,2 & 18,3 & 17,5 & 14,9 & 11,8 & 10,8 & 9,7 \\
\hline зарубежья, \% & & & & & & & & \\
\hline
\end{tabular}

* Не весь экспорт и импорт в ближнее зарубежье распределен по конкретным странам, поэтому итоговый показатель превышает сумму данных по столбцам.

Динамика рассмотренных показателей свидетельствует о том, что процесс дезинтеграции экономик на постсоветском пространстве еще не закончился. Среди основных ее причин можно выделить следующие три.

Исторически первая. Высокий уровень интеграции бывших союзных республик имел отчасти принудительный характер. И юридические, и физические лица в СССР не имели права выбора между покупкой советской продукции и ее импортных аналогов. И если бы такой выбор появился, многие сделали бы его в пользу импортной продукции (даже если бы цены на нее были завышенными). Распад СССР дал такое право, и приоритеты потребителей стали смещаться в пользу импортной продукции. Поначалу сильно заниженные реальные обменные курсы национальных валют сохраняли относительную дешевизну товаров, производимых на постсоветском пространстве, по сравнению с поступающими из дальнего зарубежья, что защищало внутренний рынок. Но по мере роста этих курсов импортные товары становились относительно все более дешевыми.

Вторая. Негативную роль в ослаблении интеграции экономик сыграли, конечно, и политические факторы. Межнациональные конфликты, появление новых государств на территории бывших республик не без содействия (явного или представляемого таким) «внешних сил» - главная причина резкого снижения объемов экономического сотрудничества не только России с Грузией и Украиной. Почти на нуле экономические связи Армении и Азербайджана, большая напряженность в отношениях между Узбекистаном и Таджикистаном. Часть стран перешла на закупки вооружений натовских стандартов. И т. д.

Третья - не менее актуальная для современного этапа. Многим государствам просто нечего предложить своим соседям для значительного расширения взаимного товарооборота. Даже у дружественного Казахстана, члена Организации Договора о коллективной безопасности, ЕврАзЭС и Таможенного союза, доля России в суммарном экспорте всего около 10\% - главными экспортными товарами этой страны Россия обеспечена в избытке. Сельскохозяйственный потенциал среднеазиатских государств невелик, и во многих сельхозпродуктах они сами остро нуждаются. Переход на интеграцию по российско-белорусскому образцу, с интенсивным обменом продукцией обрабатывающей промышленности, теоретически был возможен лишь в отношениях с Украиной, но не состоялся. И не только из-за событий 2014 г. - даже в период, когда экономика Украины превосходила по объему ВВП белорусскую в три раза и более, в отдельные годы торговый оборот между Россией и Украиной уступал аналогичному показателю между Россией и Белоруссией.

И Россия пока не может предложить многим странам широкий ассортимент необходимых им товаров. Либо мы их не производим, либо есть поставщики более дешевых и, что 
особенно актуально для самых бедных стран, - очень дешевых подержанных.

Совместные энергетические проекты, транспортные коридоры и прочие проекты в какой-то мере могут вести к усилению интеграции, но не радикальным образом. А перспективы для производственной кооперации в части обрабатывающей промышленности пока не представляются оптимистичными.

\section{Литература}

1. Гранберг А. Г., Зайкин В. С., Селиверстов В. Е. Российская Федерация в общесоюзной экономике (межотраслевой анализ) /ИЭОПП СО АН СССР. - Новосибирск: Наука. Сиб. отд-е, 1981. - 287 с. 2. Гранберг А.Г. Межреспубликанские экономические связи // Вестник Российской академии наук. - 1992. - № 2. - С. 4-14.

3. Гранберг А. Г., Суслов В. И. Коалиционный анализ многорегиональных систем: теория, методология, результаты анализа (СССР накануне распада): науч. докл./ИЭОПП СО РАН. - Новосибирск, 1993. - 63 c.

4. Ершов Ю. С. Межреспубликанский аспект развития экономики СССР накануне раздела страны/ Сб. науч. тр. Экономика регионов: внутренние возможности и ресурсы взаимодействия. ИЭиОПП СО PAH, 1998. - С. 3-29.

5. Россия и страны мира: стат. сб. - М.: Росстат, 2014 и более ранние издания.

6. Российский стат. ежегодник: стат. сб. - М.: Росстат, 2015 и более ранние издания.

7. Ершов Ю.С. Экономическое соревнование регионов России// Регион: экономика и социология. - 2016. - № 1. - С. 83-107.

8. Ершов Ю.С. Особенности национальной экономики, или почему Россия не стала Америкой. И не будет, если... // ЭКО. 2016. - № 2. - C. 69-92. 